\title{
Detection of Human Pharmaceuticals in the Surface Water of East Fork Stones River
}

\author{
Ravneet Kaur¹, Anonya Akuley-Amenyenu1, Karnita G. Garner², Sam 0. Dennis ${ }^{1 *}$ \\ ${ }^{1}$ Department of Agricultural and Environmental Sciences, College of Agriculture, Tennessee State University, Nashville, TN, USA \\ ${ }^{2}$ Alabama Cooperative Extension System, Alabama A\&M University, Normal, AL, USA \\ Email: ^sdennis@tnstate.edu
}

How to cite this paper: Kaur, R., Akuley-Amenyenu, A., Garner, K.G. and Dennis, S.O. (2020) Detection of Human Pharmaceuticals in the Surface Water of East Fork Stones River. Journal of Water Resource and Protection, 12, 240-259. https://doi.org/10.4236/jwarp.2020.123015

Received: November 8, 2019

Accepted: March 13, 2020

Published: March 16, 2020

Copyright $(\odot) 2020$ by author(s) and Scientific Research Publishing Inc. This work is licensed under the Creative Commons Attribution International License (CC BY 4.0).

http://creativecommons.org/licenses/by/4.0/

\begin{abstract}
Pharmaceuticals have been detected nationwide in different environmental matrices including wastewater effluents and surface water. In recent studies, pharmaceuticals have also been found in aquatic plants, fish tissues and plasma of shark bulls. Pharmaceuticals that were detected as indicated in published literature, included steroids, prescription drugs such as antibiotics, anti-depressants, anti-inflammatory drugs, hormones and over the counter (OTC) drugs. We conducted a monitoring study to detect the presence of pharmaceuticals in East fork of the Stones River located in Rutherford County in Middle Tennessee. East Fork Stones River is a six (6) order river that drains a large portion of Rutherford County including Murfreesboro, Tennessee. Grab water samples were collected from Stones River for three seasons: (summer and fall of 2014 and 2015 and winter of 2015 and 2016) each year. Water quality parameters were also determined in situ using Eureka Water Probes ${ }^{\mathrm{TM}}$ multi-parameter sondes. Water samples were analyzed for the presence of pharmaceutical compounds using GC-MS. Chemical Abstract Service Registry Numbers (CASRN or CAS) for detected pharmaceuticals were identified. Pharmaceuticals detected included those used for treatment of chronic alcoholism (Disulfiram: CAS \# 97-77-8), a compound (Thiazolidine: CAS \# 504-78-9) in the drug Thiazolidinedione which is used for the treatment of type II diabetes, a compound associated with the prevention of anti-inflammatory conditions (Methyl palmitate: CAS \# 112-39-0), and emollient in skincare (Undecane: CAS \# 1120-21-4). While the quantitative concentrations of these drugs were not determined in this study, their qualitative presence in surface water is noteworthy.
\end{abstract}

\section{Keywords}

Pharmaceuticals, East Fork Stones River, Surface Water, Water Quality 


\section{Introduction}

In the last few decades concerns have been raised about the presence, fate, and impacts of emerging contaminants that are being released in the environment. Emerging contaminants (ECs) are organic compounds manufactured synthetically and could be found in human health and hygiene products. ECs comprise a vast number of chemicals which include pharmaceuticals, personal care products, endocrine disrupting compounds, pesticides, surfactants, and industrial additives. Most of these chemicals are considered to be newly synthesized compounds and are not yet regulated. Production, consumption and subsequent release of these chemicals in significant volumes in our environment have resulted in the pollution of our ecosystem [1]. There has been an increasing awareness and emphasis among the scientific community to investigate the occurrence, and concentration of the emerging contaminants in the environment [2] [3] [4]. It is due to the growing concerns regarding the presence of these chemicals in the ecosystem especially on non-target organisms [4] [5]. Some of the risks include development of microbial resistance to antibiotics, feminization or masculinization of exposed aquatic organisms, interference with endocrine system of higher organisms, and accumulation in soil, plants, and animals [1] [4] [6] [7] [8] [9] [10]. Pharmaceuticals were recognized as emerging contaminants about two decades ago by Daughton and Ternes [11] [12]. Since then studies have been conducted regarding the occurrence and fate of these contaminants on a global scale employing increasingly sensitive analytical techniques in different environmental matrices. The studies include those done in surface water, groundwater, drinking water, tap water, and wastewater effluents [12] [13] [14]. Pharmaceuticals are chemicals used for diagnosis, treatment (cure/mitigation), alteration or prevention of disease, improvement of health condition or structure/function of the body which include both prescription and over the counter drugs [11]. Despite the research efforts made by the scientific community, we still lack complete understanding of the fate and bioaccumulation of these chemicals in the environment [15]. Pharmaceuticals are one of the most commonly detected chemicals under emerging contaminants [16] [17] [18] [19] [20]. In particular, the compounds that are being addressed include prescription drugs, over the counter drugs, and antibiotics. There are several pathways by which these chemicals can enter and persist in the environment. Activities such as flushing unused or expired prescriptions or over the counter drugs; the improper disposal of drugs by hospitals and manufacturers may also be the conduits for these chemicals into the environment [1] [4] [10] [21] [22] [23]. A typical household allows for numerous and extensive routes of entry of pharmaceuticals into the environment. Certainly, the manufacturing and packaging facilities for these drugs also contribute to the transportation of pharmaceuticals into the environment. Unfortunately, wastewater treatment facilities are not engineered to eliminate these non-biodegradable contaminants (pharmaceuticals) from sewage sludge. Most of the traditional wastewater treatment plants use 
primary and secondary treatment techniques that are not capable of removing these contaminants from water. Due to this reason, sewage treatment plants have been recognized as a main pathway of entry for these pharmaceuticals into water bodies and especially during outfall discharges in surface water environment [1] [12] [17] [24] [25] [26] [27]. Moreover, US wastewater treatment facilities still lack the infrastructure to analyze treated water for the presence of these contaminants. Most wastewater treatment plants use activated sludge treatment. However some studies have provided alternative methods to improve removal efficiency of wastewater in treatment plants, especially organic chemicals [28] [29].

Some of the new suggested treatments include ozonation, reverse osmosis, nanofiltration, and activated carbon filters that can provide removal efficiency of up to 99 percent. However, these aforementioned methods are expensive. They could result in metabolites that can potentially be more harmful than the parent organic chemicals [1] [30] [31]. Additionally, the chemical contaminants in the wastewater have been shown to enter surface water through combined sewer overflow during wet weather conditions. The production and consumption of pharmaceuticals are expected to continue to increase partly due to the increase in population and urbanization. Moreover, increase in population will result in the higher production of existing drugs and the discovery of new drugs. Consequently, it will result in continuous and additional release of these chemicals in the environment [15] [32] [33]. One of the biggest concerns regarding the presence of pharmaceuticals in the ecosystem is the lack of information regarding possible impacts that active ingredients can pose on non-target organisms. Studies have shown that pharmaceuticals have been detected in the concentrations range of part-per-trillion $(\mathrm{ng} / \mathrm{L})$ to parts-per-billion $(\mu \mathrm{g} / \mathrm{L})$ in both sewage treatment plant effluents and aquatic environments [4] [18] [19]. The presence of trace levels of pharmaceuticals in aquatic environment has been alluded to in several worldwide studies where these chemicals have been detected in fish tissues, plasma of bull sharks and plants [34]-[42]. Moreover, several publications published in the last 7 years reported that organic contaminants may have entered the food chain when they transfer from treated wastewater into crop plants [22] [43] [44] [45] [46] [47]. These findings are from studies performed under controlled conditions such as hydroponic cultures, laboratory, or in a greenhouse setting [22] [43] [45] [46] [48]. Studies conducted under real-world conditions are rare [22] [47]. There is a dire need to conduct more research to fill the knowledge gaps regarding potential long-term effects of these chemicals in the environment. At this time, different government and non-government organizations including the European Union (EU), the International Program of Chemical Safety (IPCS), the United States Environmental Protection Agency (EPA), and the World Health Organization (WHO) are considering these problems and setting up directives and legal frameworks to protect and improve the quality of freshwater resources [1] [49]. 
Our study is based on a watershed scale approach. This approach has been considered as the best framework to study water resource challenges because it is locally focused and it includes all local stressors and stakeholders. Therefore the objectives of the study are as delineated below:

1) To determine the temporal prevalence of pharmaceuticals in surface water of East Fork Stones River.

2) To determine water quality parameters that could affect the quality of water in the stream.

It is hypothesized that 1) the presence of pharmaceuticals in surface water contributes to the impairment of surface water quality; 2) that incidence of pharmaceuticals in the streams will fluctuate as a function of the seasons.

\section{Materials and Methods}

\subsection{Study Sites}

For this study, an urbanizing watershed from Middle Tennessee was chosen. The watershed was selected because of the associated land use and its proximity to the main campus of the university. The watershed selected was Stones River watershed (located in Rutherford County).

\section{East Fork Stones River}

East Fork Stones River (Figure 1) is a major stream in Rutherford County. According to the US Census, Rutherford County is the fifth-most populous county in Tennessee, with population of 395,000 and growing. East Fork Stones River is considered a six-order river that drains Middle Tennessee sub-watersheds. The watershed is approximately 921 square miles and drains parts of Cannon, Davidson, Rutherford and Wilson Counties. While it is considered an urbanizing watershed; land use in the county is agricultural and residential. The watershed encompasses agricultural fields of hay and pasture, some row crops, forests, and

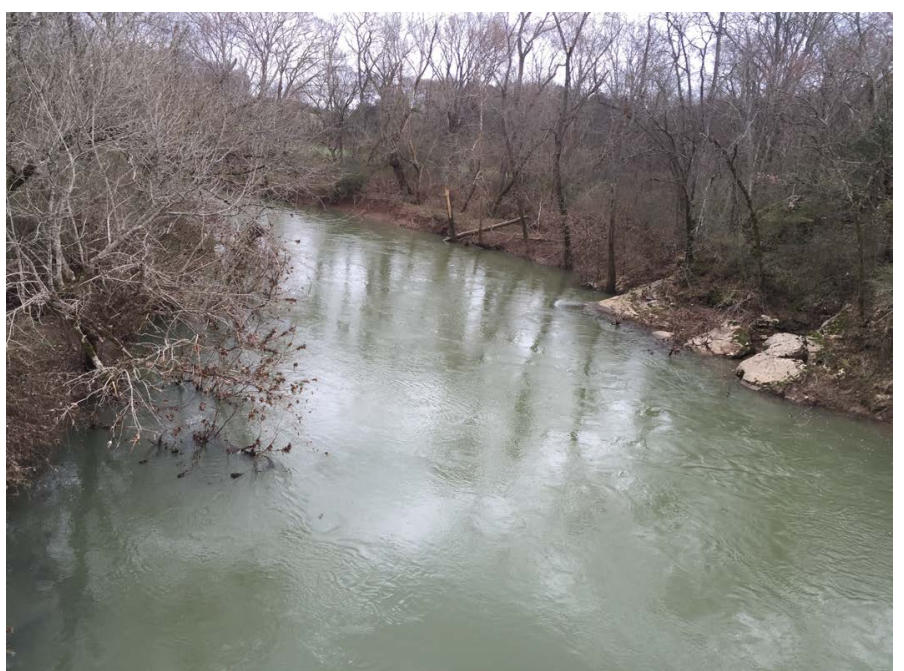

Figure 1. Sampling site for Stones River, Murfreesboro, TN (Jan 27, 2016) ( $\left.35^{\circ} 52^{\prime} 55^{\prime \prime} \mathrm{N} 86^{\circ} 16^{\prime} 19^{\prime \prime} \mathrm{W}\right)$. 
urban and industrial development. The portion of the East Fork Stones River in the study is in Murfreesboro, TN.

\subsection{Analytical Methods}

Sampling of the pharmaceuticals and physico-chemical water quality parameters was conducted for three seasons for two years: summer (2014), fall (2014), winter (2015), summer (2015), fall (2015) and winter (2016). Water sampling started during the summer of 2014. During each season, water samples were collected weekly for five consecutive weeks. Grab water samples were collected during base flow (normal flow conditions) and in some instances after rainstorm and snow events. A Teflon bailer was used to collect the water samples, as shown in Figure 2. The Teflon bailer has no interference with chemicals that are being detected in the study. Moreover, it allows the sampler to retrieve the water sample from a safe distance. Duplicate samples were collected for the pharmaceutical analysis and at the same time water samples were collected for physico-chemical analysis. The water in the bailer was emptied into $500 \mathrm{~mL}$ Low-Density Polyethylene (LDPE) sampling containers (Figure 3). Water sampling containers were kept on ice and transported to the lab, where they were stored in refrigerator at 4 degrees centigrade before analysis. During sampling, hand gloves were used in order to prevent cross-contamination with the pharmaceuticals. The pharmaceuticals were analyzed using GC-MS at a private lab (University of Georgia Environmental Analysis Laboratory).

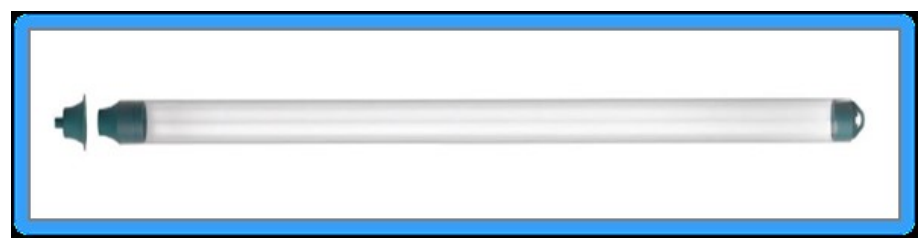

Figure 2. Instrument (Teflon bailer) used for water sample collection.

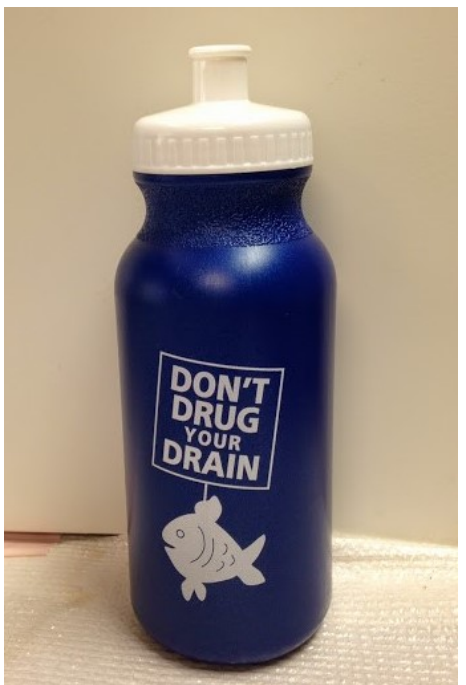

Figure 3. Sampling container. 
In-situ monitoring was conducted for water quality parameters of interest. These parameters were temperature, $\mathrm{pH}$, dissolved oxygen, and turbidity. Measurements of the parameters were taken with Eureka Manta2 ${ }^{\mathrm{TM}}$ sonde or data loggers (Eureka Water Probes, Austin TX). The data logger was interfaced with the applicable sensors, as shown in Figure 4, and deployed in the streams to at least a $45-\mathrm{cm}$ depth for about 3 minutes. Prior to deployment, the Manta data logger was calibrated according to instrument specifications. A minimum of two readings were taken in situ, and their average was used for further analysis. Additionally, the discharge rate of the sampling locations during the sampling period was obtained from the United States Geological Survey (USGS) real time database. Figure 5 and Figure 6 represented the flow rates of the East Fork Stones River during the sampling periods.

\subsection{Analysis of Water Samples for the Presence of Pharmaceuticals}

It is not uncommon that pharmaceuticals used by consumers often end up in the

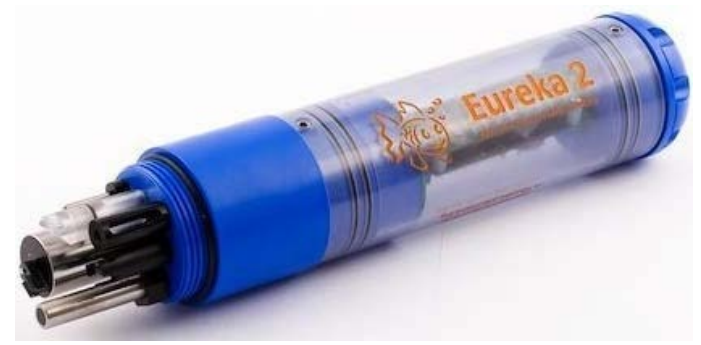

Figure 4. Data logger (Eureka Manta2 ${ }^{\mathrm{TM}}$ ) used for in situ monitoring.

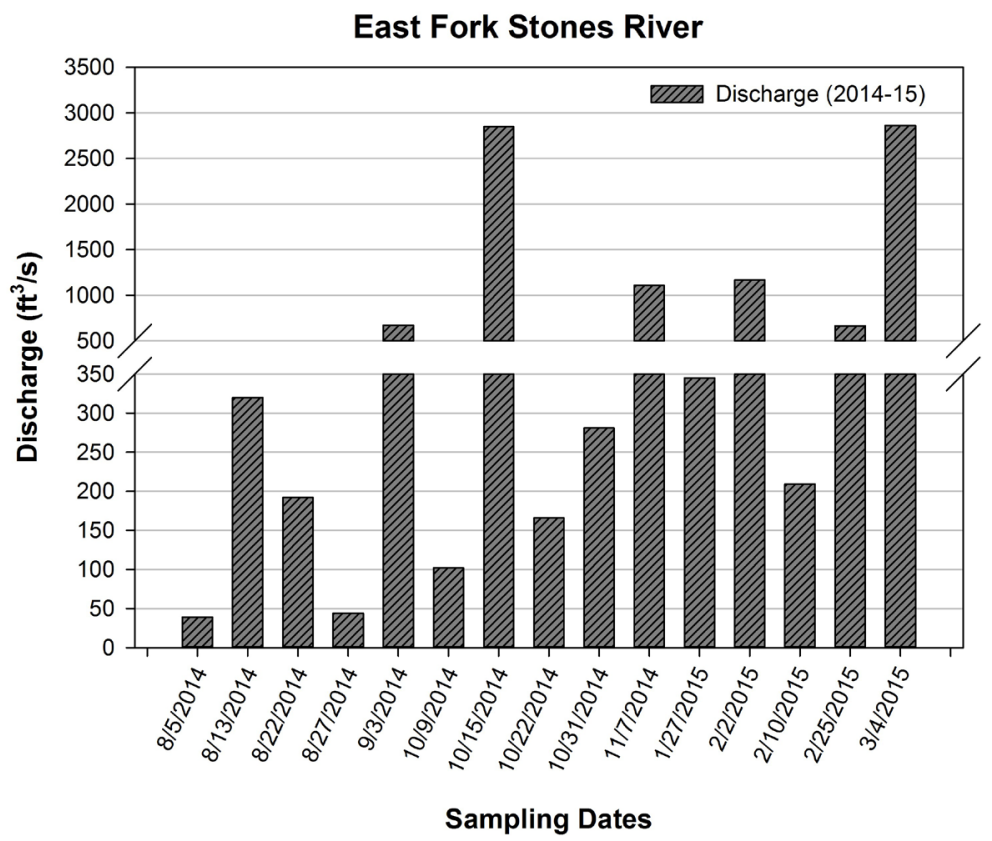

Figure 5. Discharge: East Fork Stones River (Summer 2014, Fall 2014, and Winter 2015). 


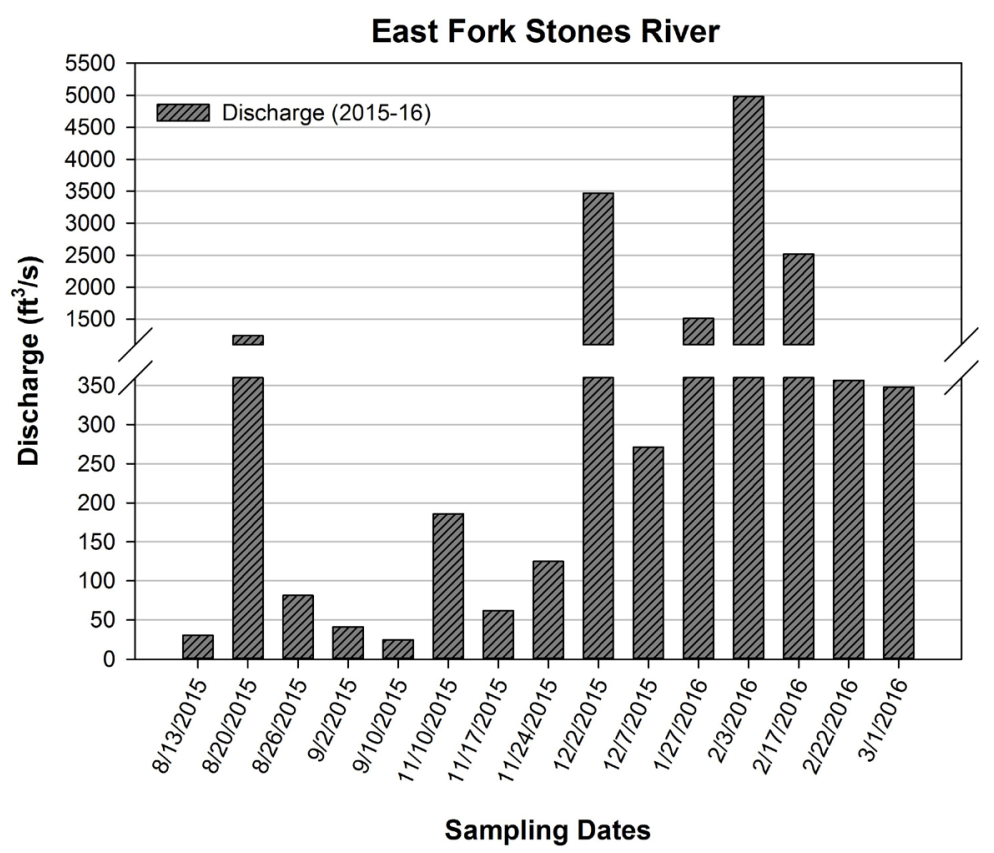

Figure 6. Discharge: East Fork Stones River (Summer 2015, Fall 2015 and Winter 2016).

wastewater treatment plants, after being washed down the drains or flushed down the toilet. Pharmaceuticals are usually bound to particles in the sludge at the wastewater treatment facility or to sediments when they are discharged into local water bodies. When pharmaceuticals are bound to particles, it is less likely that they will undergo biotransformation. The presence of natural organic matter, such as humic and fulvic acids, in the environment often complicates the analytical detection since they are coextracted with the analytes. The problems associated with sample analysis due to co-extracted compounds are collectively termed "matrix effects". Hence to achieve a successful analysis, the amount of co-extracted natural organic matter was extremely minimized in the extraction protocol. Solid-Phase Extraction (SPE) was performed to separate compounds in the sample based on their polarities and solubilities in specific solvents used for extraction. The samples were fed into the GC-MS (HP 6890 series GC System; Hewlett-Packard) where the gas chromatography separated the organic compounds, and the mass spectrometer identified the separated compounds (Figure 7). GC/MS is a technique, which combines the separating power of Gas Chromatography (GC), with the detection potential of mass spectrometry. Mass Spectrometry is a wide-ranging analytical technique, which involves the production and subsequent separation and identification of charged species according to their mass to charge $(\mathrm{m} / \mathrm{z})$ ratio.

\section{Results and Discussion}

The results consist of a two-year (2014-2016) monitoring data of pharmaceuticals in the East Fork Stones River as well as relevant water quality parameters of 


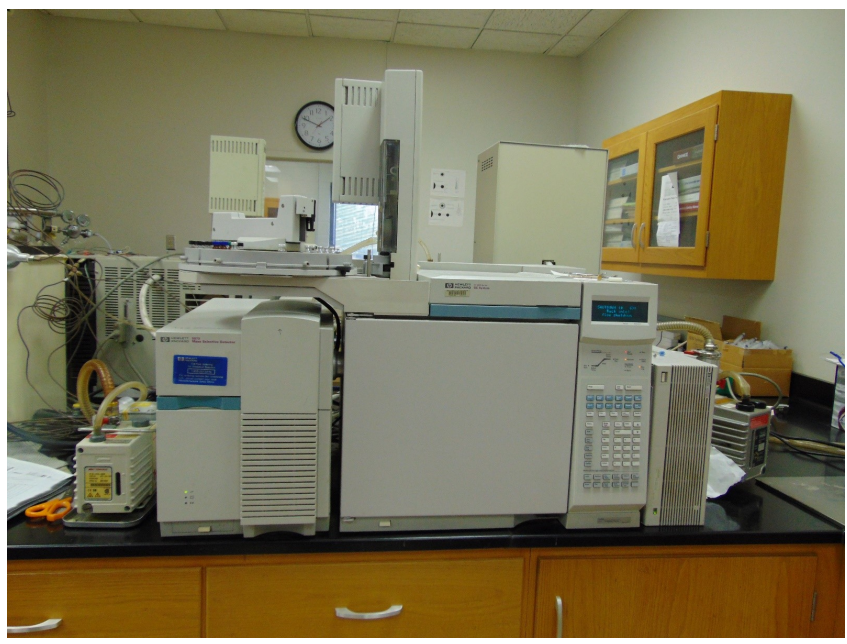

Figure 7. GC-MS used for the pharmaceutical analysis of water samples.

interest. As previously indicated, the water quality parameters of interest were temperature, $\mathrm{pH}$, dissolved oxygen, and turbidity.

\subsection{Temporal Occurrence of Pharmaceuticals in East Fork Stones River}

Pharmaceuticals detected in East Fork Stones River are presented here-in according to the seasons. The results are discussed based on the following subdivisions: 1) Pharmaceuticals detected in the East Fork Stones River during summer of 2014 and 2015 (Table 1); 2) Pharmaceuticals detected during Fall of 2014 and 2015 (Table 2); 3) Pharmaceuticals detected during Winter of 2015 and 2016 (Table 3).

The Pharmaceuticals detected during the summer of 2014 and 2015 (Table 1) included Methyl Palmitate, an anti-inflammatory and anti-fibrotic agent; Thiazolidine, a compound in the drug Thiazolidinedione (pioglitazone) which is used for the treatment of type II diabetes; and Undecane, commonly used as an intensive skin care lotion for people with eczema and psoriasis. Additionally, Disulfiram, a chronic alcohol treatment drug was detected during summer of 2014. On the other hand, Eicosane was detected during summer of 2015. Eicosane is an emollient in skin lotions and ointments and can be used for treatment of eczema and psoriasis.

Table 2 depicts the pharmaceuticals detected in the fall of 2014 and 2015. The chemicals detected in the fall of 2014 included DEET which is an insect repellent and is used as an insecticide. Another chemical was Eicosane, an emollient used as a skincare ointment, mostly used by patients suffering from eczema and psoriasis. Other pharmaceuticals detected during both fall of 2014 and 2015 included Methyl palmitate, an anti-inflammatory and anti-fibrotic agent; Thiazolidine, a compound in the drug Thiazolidinedione (pioglitazone) which is used for the treatment of type II diabetes; and Thiram, a fungicide or industrial insecticide was detected as well. Trimethoprim which is an antibiotic drug was 
Table 1. Pharmaceuticals, $\mathrm{n}=2$ : East Fork Stones River (Summer 2014, and Summer 2015).

\begin{tabular}{|c|c|c|c|c|c|}
\hline \multirow{2}{*}{$\#$} & \multirow{2}{*}{ Chemical Name } & \multirow{2}{*}{$\begin{array}{c}\text { CAS } \\
\text { Number }\end{array}$} & \multirow{2}{*}{ Use/Description } & \multicolumn{2}{|c|}{ Summer } \\
\hline & & & & 2014 & 2015 \\
\hline 1. & Disulfiram & $97-77-8$ & Chronic Alcoholism treatment & $\mathrm{X}$ & \\
\hline 2. & Eicosane & $112-95-8$ & Emollient in ointment for skincare & & $\S$ \\
\hline 3. & Methyl palmitate & $112-39-0$ & Anti-inflammatory; Anti-fibrotic & $\mathrm{X}$ & $\S$ \\
\hline 4. & Thiazolidine & $504-78-9$ & $\begin{array}{l}\text { Associated with Type II diabetes } \\
\text { treatment drug Thiazolidinediones } \\
\text { (pioglitazone) }\end{array}$ & $\mathrm{X}$ & $\S$ \\
\hline 5. & Undecane & $1120-21-4$ & Emollient in ointments for skincare & $\mathrm{X}$ & $\S$ \\
\hline
\end{tabular}

CAS Number $=$ Chemical Abstract Registry Number. $\mathrm{X}=$ Pharmaceuticals Detected-Summer 2014; $\$=$ Pharmaceuticals Detected-Summer 2015.

Table 2. Pharmaceuticals, $\mathrm{n}=2$ : East Fork Stones River (Fall 2014, and Fall 2015).

\begin{tabular}{|c|c|c|c|c|c|}
\hline \multirow{2}{*}{$\#$} & \multirow{2}{*}{ Chemical Name } & \multirow{2}{*}{$\begin{array}{c}\text { CAS } \\
\text { Number }\end{array}$} & \multirow{2}{*}{ Use/Description } & \multicolumn{2}{|c|}{ Fall } \\
\hline & & & & 2014 & 2015 \\
\hline 1. & DEET & $134-62-3$ & Insect Repellent; Insecticides & $\mathrm{X}$ & \\
\hline 2. & Eicosane & $112-95-8$ & Emollient in ointments for skincare & & $\S$ \\
\hline 3. & Methyl palmitate & $112-39-0$ & Anti-inflammatory and Anti-fibrotic & $\mathrm{X}$ & $\S$ \\
\hline 4. & Thiazolidine & $504-78-9$ & $\begin{array}{l}\text { Associated with Type II diabetes } \\
\text { treatment drug Thiazolidinediones } \\
\text { (pioglitazone) }\end{array}$ & $\mathrm{X}$ & $\S$ \\
\hline 5. & Thiram & $137-26-8$ & Fungicide; Industrial Insecticide & $\mathrm{X}$ & \\
\hline 6. & Undecane & $1120-21-4$ & Emollient in ointments for skincare & $\mathrm{X}$ & $\S$ \\
\hline
\end{tabular}

CAS Number $=$ Chemical Abstract Registry Number. $X=$ Pharmaceuticals Detected-Fall 2014; $\$=$ Pharmaceuticals Detected-Fall 2015.

Table 3. Pharmaceuticals, $\mathrm{n}=2$ : East Fork Stones River (Winter 2015, and Winter 2016).

\begin{tabular}{|c|c|c|c|c|c|}
\hline \multirow{2}{*}{$\#$} & \multirow{2}{*}{ Chemical Name } & \multirow{2}{*}{$\begin{array}{c}\text { CAS } \\
\text { Number }\end{array}$} & \multirow{2}{*}{ Use/Description } & \multicolumn{2}{|c|}{ Winter } \\
\hline & & & & 2015 & 2016 \\
\hline 1. & 1-Octadecanol & $112-92-5$ & Emollient in ointments for skincare & & $\$$ \\
\hline 2. & 3-Hexanol & $623-37-0$ & Anti-emetic drug & & $\S$ \\
\hline 3. & DEET & $134-62-3$ & Insect Repellent; Insecticides & $\mathrm{X}$ & \\
\hline 4. & Disulfiram & $97-77-8$ & Chronic Alcoholism treatment & $\mathrm{X}$ & \\
\hline 5. & Eicosane & $112-95-8$ & Emollient in ointments for skincare & $\mathrm{X}$ & $\$$ \\
\hline 6. & Thiazolidine & $504-78-9$ & $\begin{array}{l}\text { Associated with Type II diabetes } \\
\text { treatment drug Thiazolidinediones } \\
\text { (pioglitazone) }\end{array}$ & $\mathrm{X}$ & $\$$ \\
\hline 7 & Thiram & $137-26-8$ & Fungicide; Industrial Insecticide & & $\S$ \\
\hline 8. & Undecane & $1120-21-4$ & Emollient in ointments for skincare & $\mathrm{X}$ & $\$$ \\
\hline
\end{tabular}

CAS Number $=$ Chemical Abstract Registry Number. $X=$ Pharmaceuticals Detected-Winter 2015; $₫=$ Pharmaceuticals Detected-Winter 2016. 
detected in fall of 2015. Additionally, Undecane, another emollient used for skincare as an ointment was found in both fall of 2014 and 2015.

Similarly, the pharmaceuticals that were detected in the winter of 2015 and 2016 are presented in Table 3. It comprised of the 1-Octadecanol, an emollient in skincare ointments used for the treatment of eczema and psoriasis; and 3-Hexanol, an anti-emetic drug. Both chemicals were also detected during winter of 2016. The chemicals detected in winter of 2015 included DEET, an insect repellent; and Disulfiram, a drug used for chronic alcohol treatment which produces an acute sensitivity to ethanol (drinking alcohol). Among the chemicals detected in both winter of 2015 and 2016 were Eicosane, another emollient in skincare ointments and lotions which can be used for relief from eczema and psoriasis; and Thiazolidine, a compound in the drug Thiazolidinedione (pioglitazone) which is used for the treatment of type II diabetes; Thiram was another chemical that was detected in winter of 2016 and it is used by industries as fungicide and insecticide. Similarly, Undecane, a skincare emollient for eczema and psoriasis patients was also detected in both years during the winter of 2015 and 2016.

\subsection{Water Quality of the East Fork Stones River}

The motivation for selecting the parameters of interest was based on the importance of these parameters (temperature, $\mathrm{pH}$, turbidity, dissolved oxygen) in water quality. Therefore, in order to assess the water quality of the East Fork Stones River; in-situ monitoring of the water quality parameters was conducted and the findings are being reported below. Duplicate readings were taken at each location and used for further analysis.

\subsubsection{River Temperature}

Temperature tends to be the most commonly analyzed water quality parameter because it affects both the chemical and biological characteristics of the water. Moreover, every organism exhibits a preferred range or tolerance for temperature. Therefore, temperature affects the ecosystem functions of a watershed. The temperature results are presented in Figure 8. As expected East Fork Stones River was warmer in the summer months. The temperature values ranged from $7^{\circ} \mathrm{C}$ to $27^{\circ} \mathrm{C}$. The accuracy of the temperature sensor is \pm 0.1 of the reading. There was no significant difference between the temperature of the upstream and downstream locations of the River as well as between sampling years (2014-15 and 2015-16).

\subsubsection{River $\mathrm{pH}$}

$\mathrm{pH}$ is a measure of acidity or alkalinity over a $\mathrm{pH}$ range of $0-14$ in the $\mathrm{pH}$ scale. Water $\mathrm{pH}$ is a valuable indicator of chemical water quality because $\mathrm{pH}$ can influence the availability of chemicals in the water. Moreover, $\mathrm{pH}$ also affects solubility and biological availability of nutrients and heavy metals. As a result, it affects the mobility of many pollutants in a water body. 
East Fork Stones River

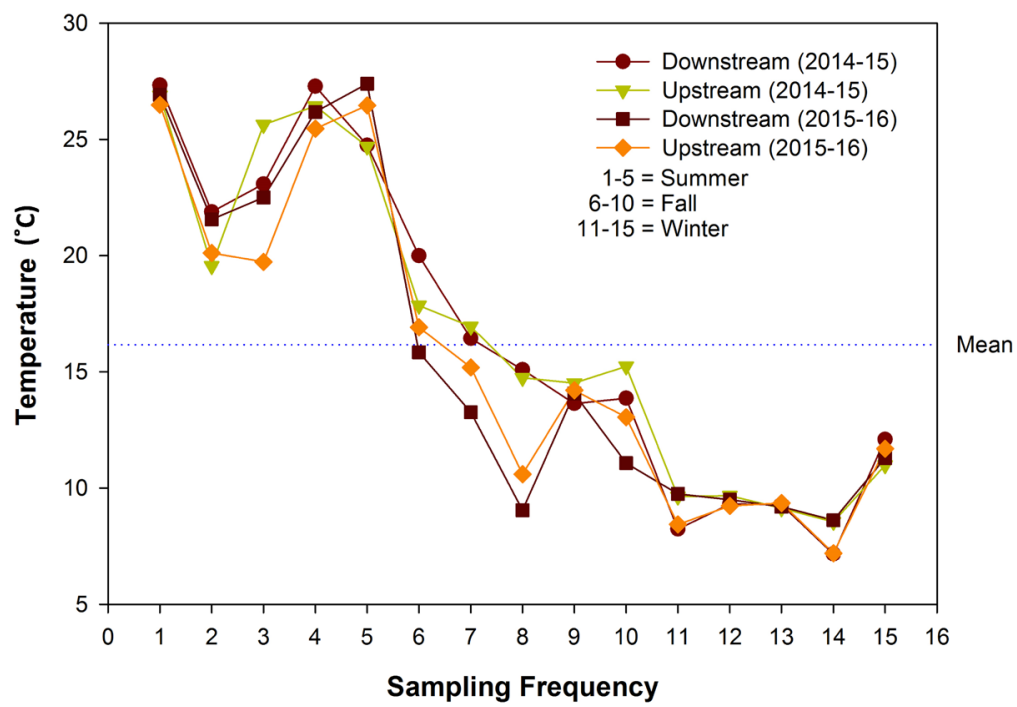

Figure 8. Temperature, $\mathrm{n}=2$ : East Fork Stones River (Summer 2014, Fall 2014, Winter 2015, Summer 2015, Fall 2015 and Winter 2016).

As shown in Figure 9, the $\mathrm{pH}$ of the River was between 7.4 to 8.5. The accuracy of the electrode is \pm 0.1 of the reading. Rainfall was observed during week 2 (2014) week 5 (2014 and 2015), week 7 (2014 and 2015), and week 9 (2015). A snowstorm was observed during week 12 in 2016 and during week 14 in 2015. As shown in Figure 9, an increase in $\mathrm{pH}$ was observed during these sampling rotations. Even though, $\mathrm{pH}$ tends to be higher during the rainy period and snowstorm events. The $\mathrm{pH}$ is still on the higher side of expected range. This could be due to the terrain around the river and the farming practices of nearby farms. Additionally, there was no significant difference between the upstream and downstream locations of the watershed and the sampling years.

\subsubsection{River Dissolved Oxygen}

Dissolved oxygen is a very important water quality parameter. It is highly dependent on temperature. The solubility of oxygen decreases with an increase in temperature and consequently dissolved oxygen decreases. A minimum of 5 $\mathrm{mg} / \mathrm{L}$ of dissolved oxygen is required to support aquatic life; however, a reading around $7 \mathrm{mg} / \mathrm{L}$ is ideal [50].

On the other hand, the values change significantly from summer to winter. Figure 10 shows the dissolved oxygen observed during sampling period. The dissolved oxygen for Stones River ranged from $7.5 \mathrm{mg} / \mathrm{L}$ to $14.5 \mathrm{mg} / \mathrm{L}$ with an average of $10 \mathrm{mg} / \mathrm{L}$. The accuracy of the DO sensor is \pm 0.1 of the reading. These values indicate the overall relatively good health of the river because they remain consistent throughout the sampling period of 2014 to 2016.

\subsubsection{River Turbidity}

United States Environmental Protection Agency (US-EPA) uses turbidity to measure water clarity and as an indicator for sediment load in streams. Turbidity 


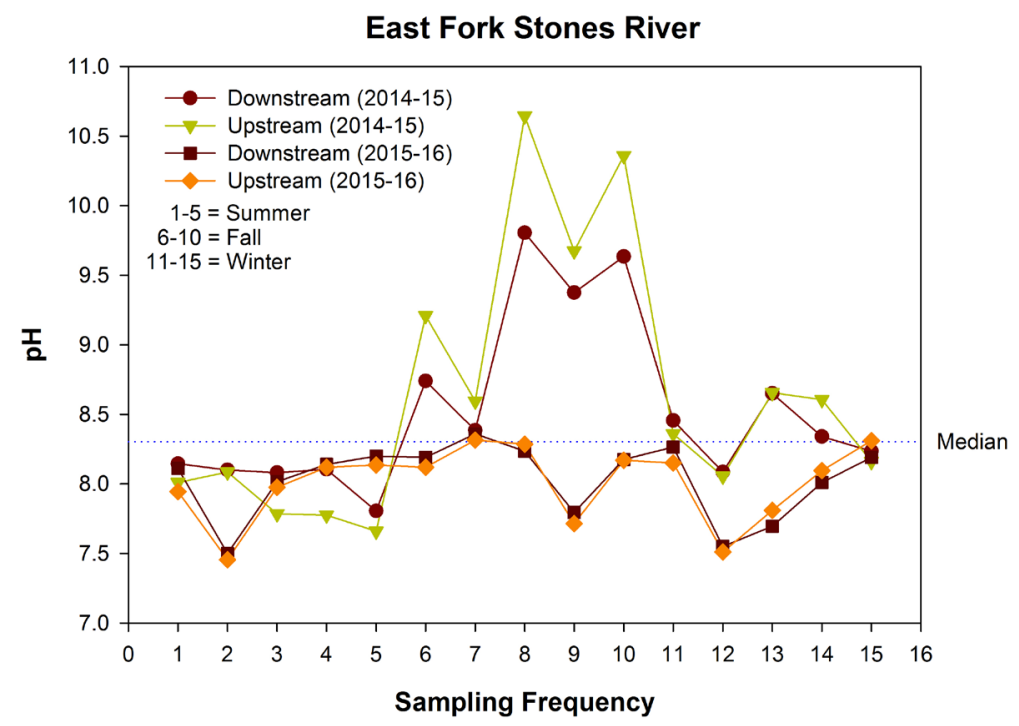

Figure 9. $\mathrm{pH}, \mathrm{n}=2$ : East Fork Stones River (Summer 2014, Fall 2014, Winter 2015, Summer 2015, Fall 2015 and Winter 2016).

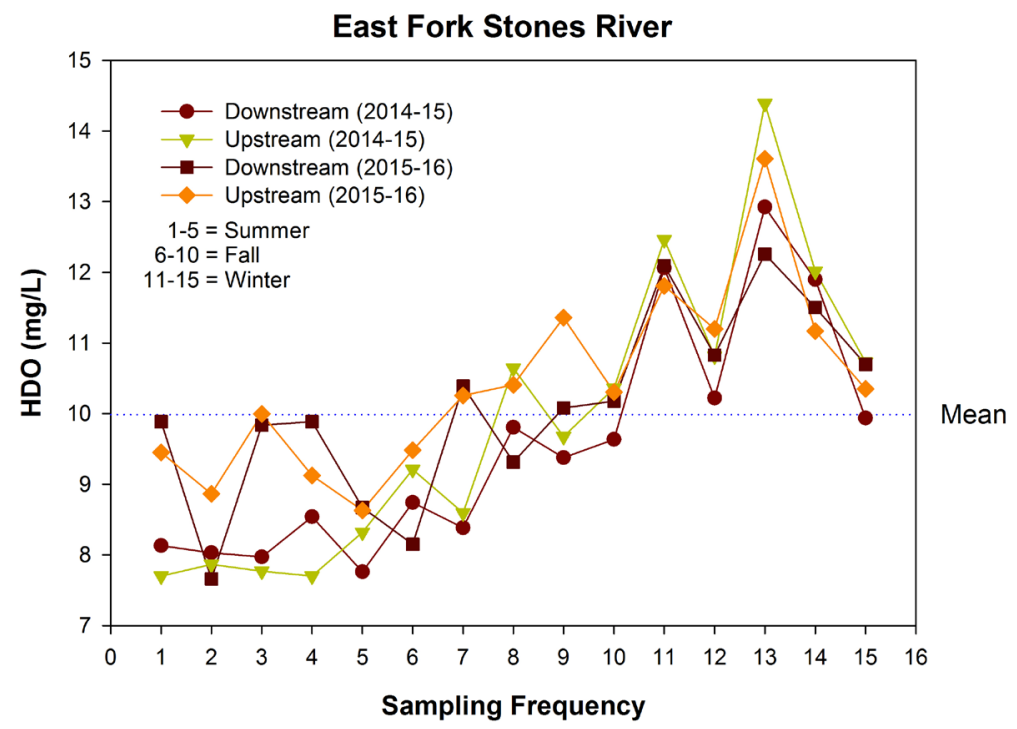

Figure 10. Dissolved oxygen, $\mathrm{n}=2$ : East Fork Stones River (Summer 2014, Fall 2014, Winter 2015, Summer 2015, Fall 2015 and Winter 2016).

is expressed by the amount of light that is scattered by material in the water when light passes through water [51]. Turbidity can be caused by several ecosystem events such as soil erosion, water discharge during urban runoff, eroding stream banks, a large number of bottom feeders, and excessive algal growth [52]. Turbidity is measured in nephelometric turbidity units (NTUs). The accuracy of the turbidity electrode is $\pm 2 \%$ of the reading. The turbidity for East Fork Stones River is depicted in Figure 11. The turbidity was higher during rainfall events (weeks 2, 5, and 7 in 2014; weeks 5, 7, and 9 in 2015), and snow events (week 12 in 2016; and week 14 in 2015). However, the overall values were within the expected range. 


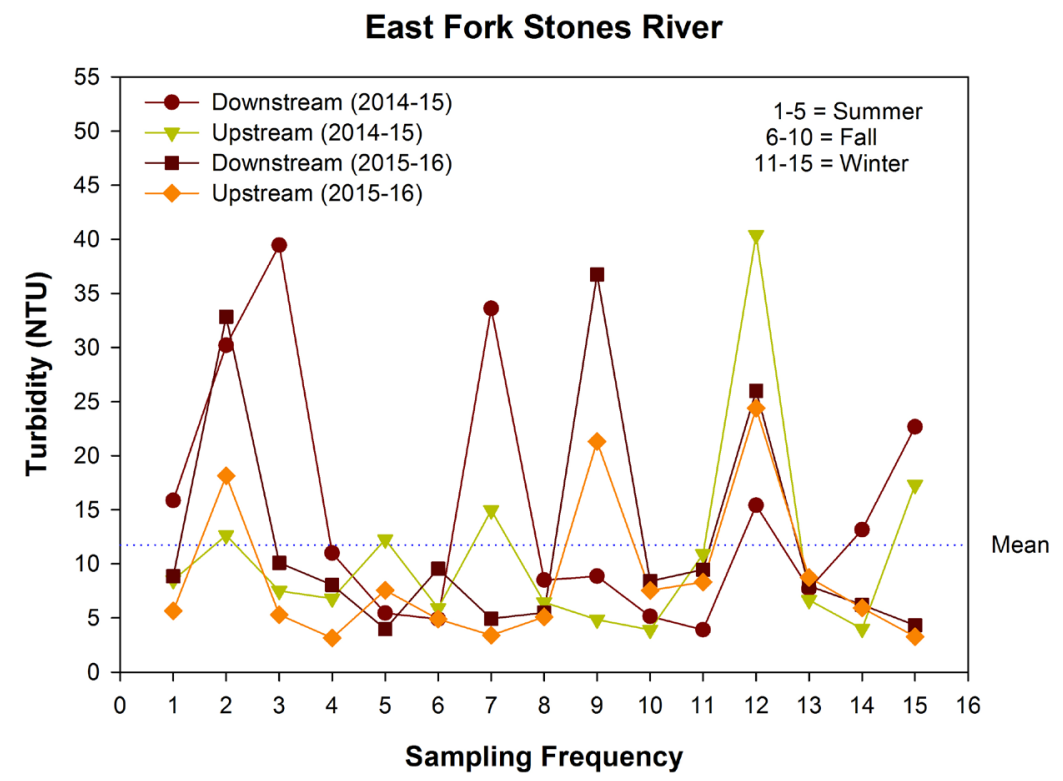

Figure 11. Turbidity, $\mathrm{n}=2$ : East Fork Stones River (Summer 2014, Fall 2014, Winter 2015, S0ummer 2015, Fall 2015 and Winter 2016).

\subsection{Seasonal Variation in Water Quality of the East Fork Stones River}

The seasonal variation in the water quality of Stones River was determined. Temperature was used as an indicator of seasonal variation. As shown in Figure $12, \mathrm{pH}$ had no correlation with temperature. As explained earlier, it remained close to the average value for most of the sampling time with exceptions during rainfall and snow events. Similarly, turbidity showed no interaction with temperature (Figure 13) and the pattern was similar to $\mathrm{pH}$. On the other hand, dissolved oxygen showed a significant relationship with temperature during both years. As shown in Figure 14, the dissolved oxygen tends to be lower with increase in temperature and vice-versa. It is evident from regression coefficient $\left(\mathrm{R}^{2}\right.$ $=0.77$ and 0.52 ) that there was strong correlation between dissolved oxygen and temperature. It is especially important for the overall health of the watershed. As discussed before runoff, soil erosion, excessive bottom feeders, and harmful algal blooms can trigger higher turbidity values. In general, the increase in turbidity over a period of time can increase the temperature of the River, which in turn can cause lower dissolved oxygen in the water. Since dissolved oxygen is one of the most important water quality parameter to sustain the aquatic life in water, the changes in dissolve oxygen values can have dramatic effects on the biodiversity of the system.

\section{Conclusion}

Our study provided the incidence of pharmaceuticals in surface water of an urbanizing watershed in Middle Tennessee. It is important to note that pharmaceuticals were detected throughout the sampling period. However, some of the 


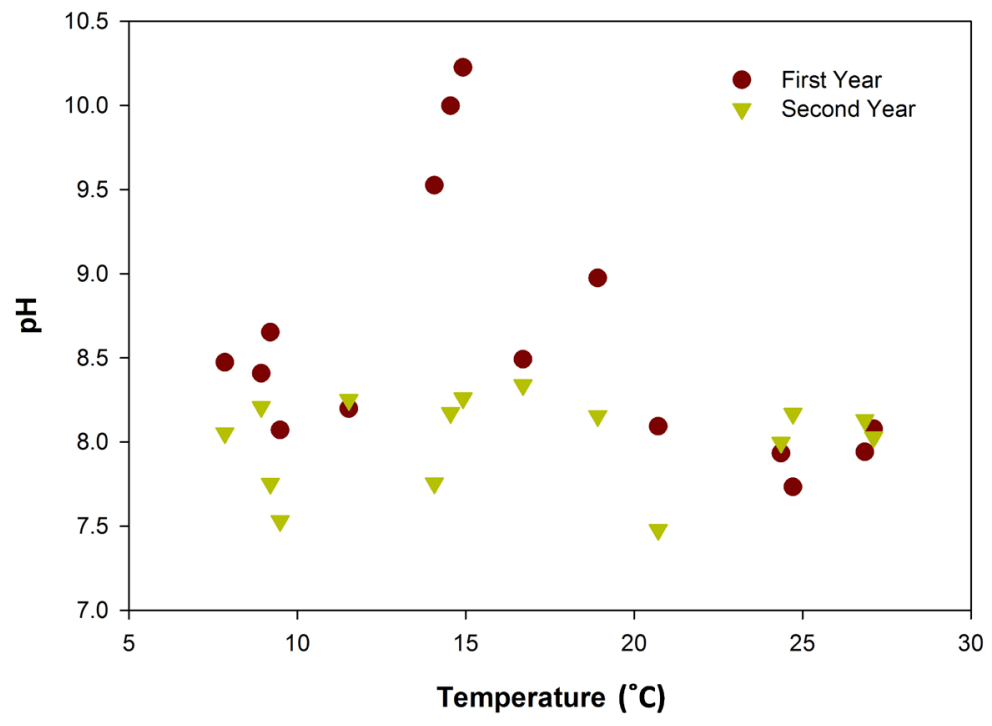

Figure 12. Relationship between temperature and $\mathrm{pH}, \mathrm{n}=2$ : East Fork Stones River (Summer 2014, Fall 2014, Winter 2015, Summer 2015, Fall 2015 and Winter 2016).

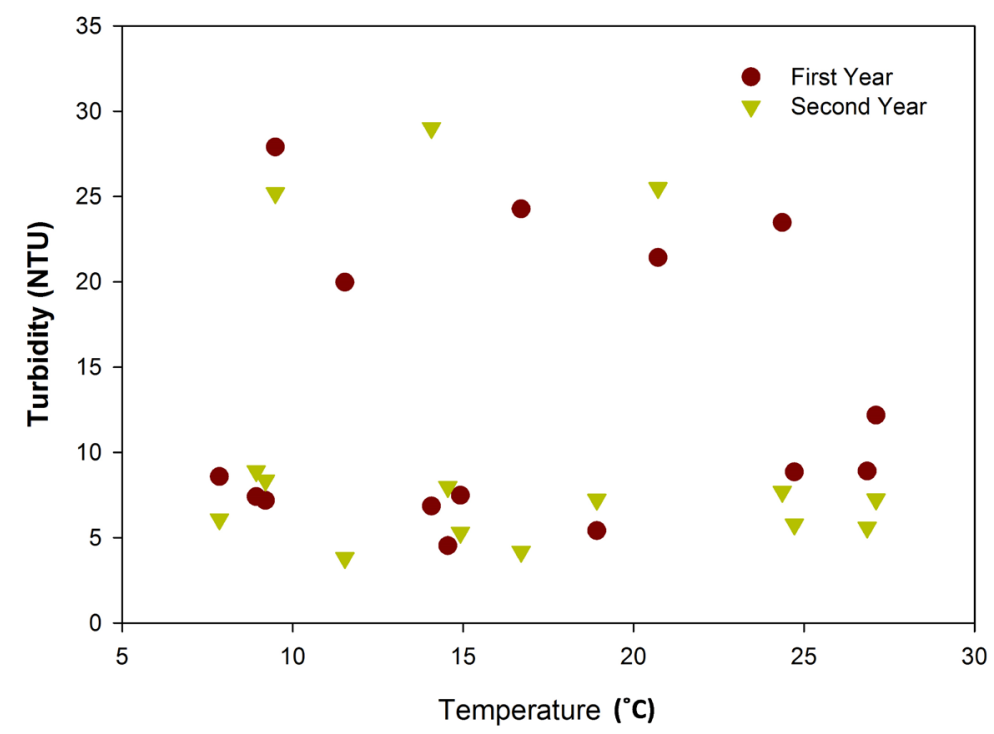

Figure 13. Relationship between temperature and turbidity, $n=2$ : East Fork Stones River (Summer 2014, Fall 2014, Winter 2015, Summer 2015, Fall 2015 and Winter 2016).

pharmaceuticals were detected more often than others. Central to these pharmaceuticals were Thiazolidine a drug associated with a type II diabetes treatment drug Thiazolidinedione (pioglitazone), Methyl palmitate (an anti-inflammatory compound), DEET (an insect repellent), and Undecane (an emollient in ointments used for skin care). It is very likely that occurrence of these pharmaceuticals may be linked to their widespread use by humans. However, the manufacturers are coming up with alternatives to reduce or eliminate the release of these chemicals in the environment. One such example is the 


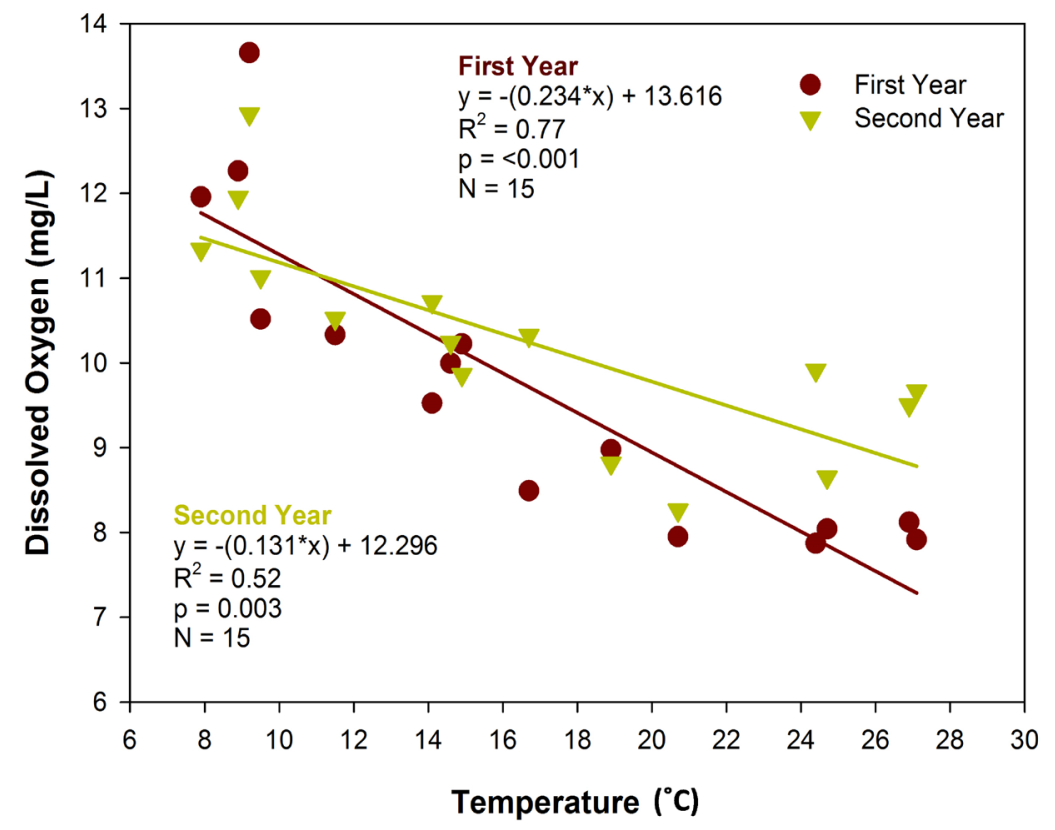

Figure 14. Relationship between temperature and dissolved oxygen, $\mathrm{n}=2$ : East Fork Stones River (Summer 2014, Fall 2014, Winter 2015, Summer 2015, Fall 2015 and Winter 2016).

availability of new insect repellents sold over the counter (OTC), which use natural compounds and they are DEET free. However, as mentioned previously, the organic chemicals present in these pharmaceuticals are non-biodegradable. Therefore, when released into the environment they tend to persist for a long time until they are removed by some emerging technology. It is imperative to educate the public about the presence and potential effects of these chemicals in our environment. It has been alluded to by several studies that improper disposal of these organic chemicals is one of the pathways to the environment [1] [4] [10] [21] [22] [23]. Therefore, ensuring a proper disposal of the organic chemicals such as pharmaceuticals will certainly reduce the drug load in our aquatic environment. At the same time wastewater treatment facilities need to adopt newer technologies that can provide better removal of the organic chemicals. Future studies can focus on examining the alternative technologies that can efficiently remove the organic chemicals from wastewater. Since, the potential effects of pharmaceuticals in non-target organisms are still not established. Further studies in this area can shed some light on the scope of the problem.

\section{Acknowledgements}

This study was funded by USDA-NIFA (Evans-Allen program) and the College of Agriculture at Tennessee State University. We would like to acknowledge Dr. Sayed M. Hassan and his team at Environmental Analysis Laboratory at the University of Georgia, Athens, GA for providing their assistance in the analysis of water samples. 


\section{Conflicts of Interest}

The authors declare no conflicts of interest regarding the publication of this paper.

\section{References}

[1] Ahmed, M.B., Zhou, J.L., Ngo, H.H., Guo, W., Thomaidis, N.S. and Xu. J. (2017) Progress in the Biological and Chemical Treatment Technologies for Emerging Contaminant Removal from Wastewater: A Critical Review. Journal of Hazardous Materials, 323, 274-298. https://doi.org/10.1016/j.jhazmat.2016.04.045

[2] Agunbiade, F.O. and Moodley, B. (2015) Occurrence and Distribution Pattern of Acidic Pharmaceuticals in Surface Water, Wastewater, and Sediment of the Msunduzi River, Kwazulu-Natal, South Africa. Environmental Toxicology and Chemistry, 31, 36-46. https://doi.org/10.1002/etc.3144

[3] Brun, G.L., Bernier, M., Losier, R., Doe, K., Jackman, P. and Lee, H.B. (2006) Pharmaceutically Active Compounds in Atlantic Canadian Sewage Treatment Plant Effluents and Receiving Waters, and Potential for Environmental Effects as Measured by Acute and Chronic Aquatic Toxicity. Environmental Toxicology and Chemistry, 25, 2163-2176. https://doi.org/10.1897/05-426R.1

[4] Carucci, A., Cappai, G. and Piredda, M. (2006) Biodegradability and Toxicity of Pharmaceuticals in Biological Wastewater Treatment Plants. Journal of Environmental Science and Health, Part A, 41, 1831-1842. https://doi.org/10.1080/10934520600779000

[5] Benotti, M.J. and Brownawell, B.J. (2009) Microbial Degradation of Pharmaceuticals in Estuarine and Coastal Seawater. Environmental Pollution, 157, 994-1002. https://doi.org/10.1016/j.envpol.2008.10.009

[6] Belhaj, D., Baccar, R., Jaabiri, I., Bouzid, J., Kallel, M., Ayadi, H. and Zhou, J.L. (2015) Fate of Selected Estrogenic Hormones in an Urban Sewage Treatment Plant in Tunisia (North Africa). Science of the Total Environment, 505, 154-160. https://doi.org/10.1016/j.scitotenv.2014.10.018

[7] Ekpeghere, K.I., Lee, J.W., Kim, H.Y., Shin, S.K. and Oh, J.E. (2017) Determination and Characterization of Pharmaceuticals in Sludge from Municipal and Livestock Wastewater Treatment Plants. Chemosphere, 168, 1211-1221. https://doi.org/10.1016/j.chemosphere.2016.10.077

[8] Gao, L., Shi, Y., Li, W., Niu, H., Liu, J. and Cai, Y. (2012) Occurrence of Antibiotics in Eight Sewage Treatment Plants in Beijing, China. Chemosphere, 86, 665-671. https://doi.org/10.1016/j.chemosphere.2011.11.019

[9] Huang, J.J., Hu, H.Y., Tang, F., Li, Y., Lu, S.Q. and Lu, Y. (2011) Inactivation and Reactivation of Antibiotic Resistant Bacteria by Chlorination in Secondary Effluents of a Municipal Wastewater Treatment Plant. Water Research, 45, 2775-2781. https://doi.org/10.1016/j.watres.2011.02.026

[10] Zhu, Y.G., Johnson, T.A., Su, J.Q., Qiao, M., Guo, G.X. and Stedtfeld, R.D. (2013) Diverse and Abundant Antibiotic Resistance Genes in Chinese Swine Farms. Proceedings of the National Academy of Sciences of the United States of America, 110, 3435-3440. https://doi.org/10.1073/pnas.1222743110

[11] Daughton, C.G. and Ternes, T.A. (1999) Pharmaceuticals and Personal Care Products in the Environment: Agents of Subtle Change? Environmental Health Perspectives, 107, 907-938. https://doi.org/10.1289/ehp.99107s6907

[12] Papageorgiou, M., Kosma, C. and Lambropoulou, D. (2016) Seasonal Occurrence, 
Removal, Mass Loading and Environmental Risk Assessment of 55 Pharmaceuticals and Personal Care Products in a Municipal Wastewater Treatment Plant in Central Greece. Science of the Total Environment, 543, 547-569. https://doi.org/10.1016/j.scitotenv.2015.11.047

[13] Blair, B.D., Crago, J.P., Hedman, C.J. and Klaper, R.D. (2013) Pharmaceuticals and Personal Care Products Found in the Great Lakes above Concentrations of Environmental Concern. Chemosphere, 93, 2116-2123. https://doi.org/10.1016/j.chemosphere.2013.07.057

[14] Rubirola, A., Llorca, M., Rodriguez-Mozaz, S., Casas, N., Rodriguez-Roda, I. and Barceló, D. (2014) Characterization of Metoprolol Biodegradation and Its Transformation Products Generated in Activated Sludge Batch Experiments and in Full Scale WWTPs. Water Research, 63, 21-32.

https://doi.org/10.1016/j.watres.2014.05.031

[15] Richmond, E.K., Grace, M.R., Kelly, J.J., Reisinger, A.J., Rosi, E.J. and Walters, D.M. (2017) Pharmaceuticals and Personal Care Products (PPCPs) Are Ecological Disrupting Compounds (EcoDC). Elementa: Science of the Anthropocene, 5, 66. https://doi.org/10.1525/elementa.252

[16] Caldas, S.S., Rombaldi, C., De Oliveira Arias, J.L., Marube, L.C. and Primel, E.G. (2016) Multi-Residue Method for Determination of 58 Pesticides, Pharmaceuticals and Personal Care Products in Water Using Solvent Demulsification Dispersive Liquid-Liquid Microextraction Combined with Liquid Chromatography-Tandem Mass Spectrometry. Talanta, 146, 676-688. https://doi.org/10.1016/j.talanta.2015.06.047

[17] De, V., Gaffney, J., Almeida, C.M.M., Rodrigues, A., Ferreira, E., Jo-Ao Benoliel, M., Eepal, S.A., et al. (2015) Occurrence of Pharmaceuticals in a Water Supply System and Related Human Health Risk Assessment.

[18] Deo, R.P. (2014) Pharmaceuticals in the Surface Water of the USA: A Review. Current Environmental Health Reports, 1, 113-122. https://doi.org/10.1007/s40572-014-0015-y

[19] Ebele, A.J., Abou-Elwafa Abdallah, M. and Harrad, S. (2017) Pharmaceuticals and Personal Care Products (PPCPs) in the Freshwater Aquatic Environment. Emerging Contaminants, 3, 1-16. https://doi.org/10.1016/j.emcon.2016.12.004

[20] Madikizela, L.M., Tavengwa, N.T. and Chimuka, L. (2017) Status of Pharmaceuticals in African Water Bodies: Occurrence, Removal and Analytical Methods. Journal of Environmental Management, 193, 211-220. https://doi.org/10.1016/j.jenvman.2017.02.022

[21] Daughton, C. (2007) Green Pharmacy: Preventing Pharmaceutical Pollution. Journal of Ecology and Toxicology, 4-13.

[22] Riemenschneider, C., Al-Raggad, M., Moeder, M., Seiwert, B., Salameh, E. and Reemtsma, T. (2016) Pharmaceuticals, Their Metabolites and Other Polar Pollutants in Field-Grown Vegetables Irrigated with Treated Municipal Wastewater. Journal of Agricultural and Food Chemistry, 64, 5784-5792. https://doi.org/10.1021/acs.jafc.6b01696

[23] Sui, Q., Zhao, W., Cao, X., Lu, S., Qiu, Z., Gu, X. and Yu, G. (2017) Pharmaceuticals and Personal Care Products in the Leachates from a Typical Landfill Reservoir of Municipal Solid Waste in Shanghai, China: Occurrence and Removal by a Full-Scale Membrane Bioreactor. Journal of Hazardous Materials, 323, 99-108. https://doi.org/10.1016/j.jhazmat.2016.03.047

[24] Ekberg, B.M.P. and Pletsch, B.A. (2011) Pharmaceuticals and Personal Care Prod- 
ucts (PPCPs) in the Streams and Aquifers of the Great Miami River Basin. The Miami Conservancy District.

[25] Focazio, M.J., Kolpin, D.W., Barnes, K.K., Furlong, E.T., Meyer, M.T., Zaugg, S.D., Barber, L.B. and Thurman, M.E. (2008) A National Reconnaissance for Pharmaceuticals and Other Organic Wastewater Contaminants in the United States-II) Untreated Drinking Water Sources. Science of the Total Environment, 402, 201-216. https://doi.org/10.1016/j.scitotenv.2008.02.021

[26] Kolpin, D.W., Furlong, E.T., Meyer, M.T., Thurman, E.M., Zaugg, S.D., Barber, L.B. and Buxton, H.T. (2002) Pharmaceuticals, Hormones and Other Organic Wastewater Contaminants in U.S. Streams, 1999-2000: A National Reconnaissance. Environmental Science \& Technology, 36, 1202-1211. https://doi.org/10.1021/es011055j

[27] Sgroi, M., Roccaro, P., Korshin, G.V., Greco, V., Sciuto, S., Anumol, T., Snyder, S.A. and Vagliasindi, F.G.A. (2017) Use of Fluorescence EEM to Monitor the Removal of Emerging Contaminants in Full Scale Wastewater Treatment Plants. Journal of Hazardous Materials, 323, 367-376. https://doi.org/10.1016/j.jhazmat.2016.05.035

[28] de Wilt, A., van Gijn, K., Verhoek, T., Vergnes, A., Hoek, M., Rijnaarts, H. and Langenhoff, A. (2018) Enhanced Pharmaceutical Removal from Water in a Three Step Bio-Ozone-Bio Process. Water Research, 138, 97-105. https://doi.org/10.1016/j.watres.2018.03.028

[29] Miralles-Cuevas, S., Oller, I., Agüera, A., Llorca, M., Sánchez Pérez, J.A. and Malato, S. (2017) Combination of Nanofiltration and Ozonation for the Remediation of Real Municipal Wastewater Effluents: Acute and Chronic Toxicity Assessment. Journal of Hazardous Materials, 323, 442-451. https://doi.org/10.1016/j.jhazmat.2016.03.013

[30] Tröger, R., Klöckner, P., Ahrens, L. and Wiberg, K. (2018) Micropollutants in Drinking Water from Source to Tap-Method Development and Application of a Multiresidue Screening Method. Science of the Total Environment, 627, 1404-1432. https://doi.org/10.1016/j.scitotenv.2018.01.277

[31] Zhang, S., Gitungo, S., Axe, L., Dyksen, J.E. and Raczko, R.F. (2016) A Pilot Plant Study Using Conventional and Advanced Water Treatment Processes: Evaluating Removal Efficiency of Indicator Compounds Representative of Pharmaceuticals and Personal Care Products. Water Research, 105, 85-96. https://doi.org/10.1016/j.watres.2016.08.033

[32] Brooks, B.W. (2018) Urbanization, Environment and Pharmaceuticals: Advancing Comparative Physiology, Pharmacology and Toxicology. Conservation Physiology, 6, cox079. https://doi.org/10.1093/conphys/cox079

[33] Weber, F.A., Bergmann, A., Hickmann, S., Ebert, I., Hein, A., et al. (2015) Pharmaceuticals in the Environment-Global Occurrences and Perspectives. Environmental Toxicology and Chemistry, 35, 823-835. https://doi.org/10.1002/etc.3339

[34] Bartrons, M. and Penuelas, J. (2017) Pharmaceuticals and Personal Care Products in Plants. Trends in Plant Science, 22, 194-203. https://doi.org/10.1016/j.tplants.2016.12.010

[35] Bhalsod, G.D., Chuang, Y.H., Jeon, S., Gui, W., Li, H., Ryser, E.T., Guber, A.K. and Zhang, W. (2018) Uptake and Accumulation of Pharmaceuticals in Overhead- and Surface-Irrigated Greenhouse Lettuce. Journal of Agricultural and Food Chemistry, 66, 822-830. https://doi.org/10.1021/acs.jafc.7b04355

[36] Deo, R.P. (2014) Pharmaceuticals in the Surface Water of the USA: A Review. Current Environmental Health Reports, 1, 113-122. https://doi.org/10.1007/s40572-014-0015-y 
[37] Foltz, J., Mottaleb, M.A., Meziani, M.J. and Islam, M.R. (2014) Simultaneous Detection and Quantification of Select Nitromusks, Antimicrobial Agent and Antihistamine in Fish of Grocery Stores by Gas Chromatography-Mass Spectrometry. Chemosphere, 107, 187-193. https://doi.org/10.1016/j.chemosphere.2013.12.032

[38] Huerta, B., Jakimska, A., Gros, M., Rodríguez-Mozaz, S. and Barceló, D. (2013) Analysis of Multi-Class Pharmaceuticals in Fish Tissues by Ultra-High-Performance Liquid Chromatography Tandem Mass Spectrometry. Journal of Chromatography A, 1288, 63-72. https://doi.org/10.1016/j.chroma.2013.03.001

[39] Puckowski, A., Mioduszewska, K., Łukaszewicz, P., Borecka, M., Caban, M., Maszkowska, J. and Stepnowski, P. (2016) Bioaccumulation and Analytics of Pharmaceutical Residues in the Environment: A Review. Journal of Pharmaceutical and Biomedical Analysis, 127, 232-255. https://doi.org/10.1016/j.jpba.2016.02.049

[40] Ramirez, A.J., Brain, R.A., Usenko, S., Mottaleb, M.A., O’Donnell, J.G., Stahl, L.L., Wathen, J.B., Snyder, B.D., Pitt, J.L., Perez-Hurtado, P., Dobbins, L.L., Brooks, B.W. and Chambliss, C.K. (2009) Pharmaceuticals and Personal Care Products in the Environment: Occurrence of Pharmaceuticals and Personal Care Products in Fish: Results of a National Pilot Study in the United States. Environmental Toxicology and Chemistry, 28, 2587-2597. https://doi.org/10.1897/08-561.1

[41] Tanoue, R., Nomiyama, K., Nakamura, H., Hayashi, T., Kim, J.-W., Isobe, T., Shinohara, R. and Tanabe, S. (2014) Simultaneous Determination of Polar Pharmaceuticals and Personal Care Products in Biological Organs and Tissues. Journal of Chromatography A, 1355, 193-205. https://doi.org/10.1016/j.chroma.2014.06.016

[42] Zenker, A., Cicero, M.R., Prestinaci, F., Bottoni, P. and Carere, M. (2014) Bioaccumulation and Biomagnification Potential of Pharmaceuticals with a Focus to the Aquatic Environment. Journal of Environmental Management, 133, 378-387. https://doi.org/10.1016/j.jenvman.2013.12.017

[43] Goldstein, M., Shenker, M. and Chefetz, B. (2014) Insights into the Uptake Processes of Wastewater-Borne Pharmaceuticals by Vegetables. Environmental Science \& Technology, 48, 5593-5600. https://doi.org/10.1021/es5008615

[44] Pan, M., Wong, C.K.C. and Chu, L.M. (2014) Distribution of Antibiotics in Wastewater-Irrigated Soils and Their Accumulation in Vegetable Crops in the Pearl River Delta, Southern China. Journal of Agricultural and Food Chemistry, 62, 11062-11069. https://doi.org/10.1021/jf503850v

[45] Shenker, M., Harush, D., Ben-Ari, J. and Chefetz, B. (2014) Uptake of Carbamazepine by Cucumber Plants: A Case Study Related to Irrigation with Reclaimed Wastewater. Chemosphere, 82, 905-910. https://doi.org/10.1016/j.chemosphere.2010.10.052

[46] Tanoue, R., Sato, Y., Motoyama, M., Nakagawa, S., Shinohara, R. and Nomiyama, K. (2012) Plant Uptake of Pharmaceutical Chemicals Detected in Recycled Organic Manure and Reclaimed Wastewater. Journal of Agricultural and Food Chemistry, 60, 10203-10211. https://doi.org/10.1021/jf303142t

[47] Wu, X., Conkle, J.L., Ernst, F. and Gan, J. (2014) Treated Wastewater Irrigation: Uptake of Pharmaceutical and Personal Care Products by Common Vegetables Under Field Conditions. Environmental Science \& Technology, 48, 11286-11293. https://doi.org/10.1021/es502868k

[48] Herklotz, P.A., Gurung, P., Heuvel, B.V. and Kinney, C.A. (2010) Uptake of Human Pharmaceuticals by Plants Grown under Hydroponic Conditions. Chemosphere, 78, 1416-1421. https://doi.org/10.1016/j.chemosphere.2009.12.048

[49] Esplugas, S., Bila, D.M., Krause, L.G.T. and Dezotti, M. (2007) Ozonation and Ad- 
vanced Oxidation Technologies to Remove Endocrine Disrupting Chemicals (EDCs) and Pharmaceuticals and Personal Care Products (PPCPs) in Water Effluents. Journal of Hazardous Materials, 149, 631-642.

https://doi.org/10.1016/j.jhazmat.2007.07.073

[50] University Wisconsin Green Bay (2005) Dissolved Oxygen. Lower Fox River Watershed Monitoring Program, Green Bay, WI.

https://www.uwgb.edu/watershed/data/chemistry.asp

[51] USEPA (2015).

https://archive.epa.gov/water/archive/web/html/vms55.html

[52] USGS (2015). https://water.usgs.gov/edu/turbidity.html 